\title{
The Impact of Innovation and Green Fiscal Incentives on Employment in Spain
}

\author{
ESTER MARTÍNEZ-ROS* \\ Universidad Carlos III de Madrid \\ RASI KUNAPATARAWONG** \\ Hitachi Consulting Thailand at $Q$ House Lumpini
}

Received: July, 2018

Accepted: May, 2019

\begin{abstract}
Questions remain whether the government is aware of difficulties of incentive schemes, its effectiveness, implications and conditions that are required so policy instrument can be put to the best use. Using a corporate tax dataset for MSMEs (micro firms) and SMEs in 2008, we use OLS to study the relationship between employment and environmental investment tax credit (EI) and technological innovation tax credit (R\&D\&I). Our results show a positive impact of EI and R\&D\&I tax credit on employment for MSMEs and SMEs. The impact is stronger for R\&D\&I tax credit than for EI tax credit and stronger for MSMEs than for SMEs. Also, the impacts of both tax credits are independent of each other. We help to provide insights into the impacts of two types of tax credits on employment level for micro and SMEs that are the backbone of an economy. The important thing is the government must remain engaged in both green and technology policies to ensure policy intervention schemes are powerful and effective.
\end{abstract}

Keywords: Environmental policy, environmental investment tax credit, technological innovation tax credit, employment, MSMEs, SMEs.

JEL Classification: M10, M21, L25, O31, O38

\section{Introduction}

Issues such as acid rain, environmental degradation, excessive and unnecessary expenditure or pollution have never been as important as today. One of the ways firms can satisfy both economic and green goals and to respond to this vigilance and constant pressure to be green is through developments of green innovations. Accordingly, many public programs and incentive policies have been put in place to encourage and support research and

\footnotetext{
* Orcid ID: 0000-0003-0088-4611.

** Orcid ID: 0000-0002-8044-5004. The author is a Go-to-Market Specialist Social Innovation Business Unit with Hitachi Consulting Thailand at Q House Lumpini, 1 South Sathorn Road, Bangkok 10120, Thailand. The views expressed in the paper are solely those of the author and not of Hitachi Consulting or any other Hitachi business unit.
} 
development $(R \& D)$ in green innovations. Tax incentives and direct funding through grants and loans are two most widely used policy instruments to motivate private entities to be environmentally responsible. While direct public funding has a long tradition, tax incentive instrument has just gradually caught up across countries (Busom et al., 2014). Tax incentive instrument aims to reduce investment costs for firms through tax deductions, ultimately lessening tax debt and increasing private profitability as well as to help firms reach optimal social production. Both theoretical and empirical evidence show that tax incentives are effective in helping firms to reduce $R \& D$ costs and to achieve market efficiency (Hall and van Reenen, 2000). Science, Technology and Industry Scoreboard report from OECD (2011a) shows that, in 2009, Canada, the Netherlands and Japan rely mostly on tax incentives, while Sweden, Finland and Germany rely almost exclusively on direct funding. France, Denmark, Spain, the United Kingdom and the United States prefer the use of both instruments simultaneously.

Environmental tax incentives vary widely among countries (European Commission, 2003). In this paper, we focus on the two tax schemes that are environmental investment tax credit (hereafter, EI) and R\&D and technological innovation tax credit (hereafter, R\&D\&I). While there is substantial empirical research studying impacts of R\&D subsidies and R\&D tax incentives on private R\&D investments (Bloom et al., 2002; Busom et al., 2014, 2017; Hall and van Reenen, 2000; Hall and Lerner 2010; Koga, 2003), this study is the first to empirically explore the relationship between the two types of tax incentives on employment. Empirical evidence is needed to understand such tax applications, implementation, implications and conditions that are required so the instrument is most effective. As such, the objective of the study is to analyze the effect of EI and R\&D\&I tax credits on employment.

We contribute to the literature by analyzing the impacts of EI and R\&D\&I tax credits on employment level for firms of different sizes. In 2008, approximately $97 \%$ of firms in Spain had 19 employees or fewer (INE, 2009). We provide more insights on very small firms that are typically left out of analyses and are often overlooked by policy makers, as compared to big businesses. Moreover, we also help fill the gap in the literature where there is still a lack of studies due to inadequate theoretical support and data. MSMEs (or micro firms) and SMEs are considered the backbone of an economy (Baumann and Kritikos, 2016). These firms are constrained by different context than for larger firms. A detailed study on them is relevant and help contribute to the literature, suggesting that customized policy schemes based on firm size are necessary. We use corporate tax records dataset in year 2008 from Institute of Fiscal Studies (IEF) of the Ministry of Finance and Public Administration of Spain and Sistema de Análisis de Balances Ibéricos (SABI) database from 2008-2010. Our total observation is 175,557 firms. Our results show that there are positive relationships between employment and EI and R\&D\&I tax credits for MSMEs and SMEs. The results further show that the impact of both tax credits on employment are independent of each other.

Given the current design of EI and R\&D\&I tax credit in the study, the implication is that private sector is responsive to EI and R\&D\&I tax incentives. As green tax schemes increase administrative costs for the government (CPB Netherlands Bureau for Economic Policy 
Analysis, 2014) the question is how policy interventions can be designed to achieve the desired positive outcomes for the society, while producing fiscal sustainability. Another question concerns in which manner firms benefit from each instrument, including the efficiency of each instrument as well as bundled as policy package and final impacts at both micro-and macro-levels (Busom et al., 2017). Better-designed regulations will help maximize co-benefits for firms and society alike.

The remainder of the paper is organized into four parts. Part two focuses on the literature. Part three presents data and methods. We analyze and discuss results in part four and conclude in part five.

\section{Literature review}

\subsection{Policies and incentives addressing sustainable development}

Governments are anchoring for policy changes towards a greener economy that place humans and their wellbeing at the center. Ecological modernization theory has been the hegemonic paradigm in guiding environmental policies worldwide (Hovardas, 2016). It advocates that implementing environmental management practices produce economic gains while reducing environmental impacts (Murphy and Gouldson, 2000; Gunderson and Yun, 2017). Based on ecological modernization theory, government regulations are important mechanisms to promote green innovations (Zhu et al., 2011). Market imperfections and various constraints create conditions where optimum level of innovation cannot be attained unless public policies are put in place to stimulate innovation (Porter and van der Linde, 1995; Rennings, 2000; OECD, 2011b). Sustainable economic growth requires innovation, advanced skills, supporting institutions, ecological ambition and necessary policies. These policies must be in alignment and inhibit short-term actions that are counterproductive. For instance, market failures associated with environmental pollution interact with market failures associated with innovation. Such combined market failures provide a strong rationale for the government to formulate public policy portfolios that foster the development and adoption of green technologies by designing green policies to raise firm incentives to minimize externalities, or potentially harmful consequences of economic activities on the environment (Jaffe et al., 2005). Especially for green innovations that face two externalities of an innovation externality and an environmental externality, Rennings (2000) argues that technologypush and market-pull factors alone do not provide enough incentives. If markets do not punish firms that produce environmentally harmful impacts, competition between green versus non-green innovators will be distorted because technology and market factors alone do not provide sufficient incentives. In the presence of weak environmental policies, investments in green innovations are likely to be less than would be desirable (Jaffe et al., 2005). Consequently, policies and regulatory framework play crucial roles in green innovation development (del Río et al., 2013; Doran and Ryan, 2016; Gerstlberger et al., 2013; Horbach et al., 2012; Rennings, 2000; Porter and van der Linde, 1995), and in determining economic 
and employment outcome (Poschen and Renner, 2015). Doran and Ryan (2016) show that existing government regulation and availability of government grants, subsidies or other financial incentives for green innovation are positive for various types of green innovations (e.g., reduce material, reduce energy, reduce pollution, recycle waste).

There are diverse green policy instruments that promote green innovations and address environmental challenges. For instance, there are regulatory approaches, market-based instruments, voluntary approaches and information-based/education-based instruments. Regulatory approach is commonly known as command-and-control that takes the form such as emission limits, discharge standards and technology ordinances. They are government interventions through formulation of relevant laws, regulations and environmental standards to set a limit on discharges (Ren et al., 2018). Yang and Yang (2015) found that policy enforcements on energy savings and emission reductions help to accelerate green innovation process. Market-based instruments or incentive-based instruments rely on prices to motivate firms to find lowest-cost means to abate activities causing environmental damages. It can be in the form of emission trading, subsidies, or tax credits. Market-based environmental regulations are found to be effective to promote green growth (Zhang et al., 2015). Zhao et al. (2015) explored the impact of command and control regulations and market-based environmental regulations and found that command and control regulations have a strong positive impact on technological innovation while market-based environmental regulations play significant roles in promoting behavioral shift towards greener development. Voluntary approach emphasizes spontaneous behaviors of market players to help control pollution emissions. It can include having the government working with industrial partners, or through voluntary regulation like public opinion, citizen participation, environmental certification and environmental information disclosure (Ren et al., 2018). Arimura et al. (2008) found that voluntary regulation is effective in reducing pollutants discharge. Kathuria (2007) also found that external pressures represented by environmental news report play a positive role in firms' pollution control. In addition, governments can also undertake information or education-based campaigns to raise awareness on environmental issues.

Specific to technology and innovation policies, tax incentives (i.e., exemptions, credits and accelerated depreciations) and direct funding through grants and loans are two most widely used policy instruments. These instruments attempt to reduce innovation costs through tax credits for R\&D expenses, labor expenses or favorable capital expenses, but not necessarily increase revenues for innovators. Most OECD countries employ tax incentives for $R \& D$ activities as $R \& D$ tax credits provide higher return to innovation efforts, therefore maintaining positive spillovers of innovation, benefiting the economy (OECD, 2011b). Between tax incentives and direct funding, literature shows that tax incentives have lower administrative burden and mitigate the risk of "picking losers" more than direct funding (Dechezleprêtre et al., 2016). Therefore, tax incentives are more market-friendly and have become more prevalent in facilitating $R \& D$ activities in both developed and developing countries (OECD, 2014c). In this manner, for this paper, we focus on analyzing the impacts of the two tax incentive schemes that were regulated by the Spanish Corporate Income tax during 2008 on employment. They are EI and R\&D\&I tax credits. 


\subsection{Environment investment (EI) tax credit and impacts on employment}

The goal of EI is to foster investments in environmental protection and to help firms comply with environmental regulations. This is a market-based or incentive-based instrument. Nielsen et al. (2014) and Zhang et al. (2015) show that coordinated market-based environmental regulations are effective and contribute to green growth. EI offers tax credit on total tangible assets invested that are devoted to environmental protection (Puig Ventosa, 2010), for instance, investments to reduce emissions and discharges (OECD, 2015). EI was first introduced in 1996 in Spain. Based on the 2004 Corporate Tax Law, 10\% tax deduction is offered to firms with environmental investment expenses, specifically tangible assets that are used to (1) avoid air pollution from industrial facilities; (2) reduce, recover or adequately treat industrial waste; and (3) generate renewable energy from selected processes. The tax credit is $12 \%$ for new land purchase and transportation for commercial or industrial use. To qualify for EI tax credit, these investments must go beyond what is legally required and must be included in programs or agreements with corresponding environmental authorities that issue a certificate validating the investments. However, this instrument has been canceled out from 2014, modifying the earlier Spanish policy in environmental issues (Agencia Tributaria, 2008; Puig Ventosa, 2010).

For the past decades, implications of environmental policies on jobs and competitiveness spurred ongoing debate. On the one hand, a pessimistic pollution haven hypothesis contends that firms will flee locations with stringent environmental regulations, resulting in diminished competitiveness, job losses and relocation to countries with laxer environmental policies (the so-called pollution havens). Such fear remains one of the main barriers to green growth. On the other hand, an optimistic Porter hypothesis contends that stringent environmental regulation leads to innovation. Yet, there is no evidence that environmental policies have systematically led to job losses due to pollution haven hypothesis (Anger and Oberndorfer, 2008; Bowen, 2012). The Organization for Economic Co-Operation and Development (OECD) also suggests that green investment has substantial potential to create jobs (OECD, 2011b; United Nations Environment (UNEP), 2011). A meta-analytic statistical experiment on environmental tax reform shows that environmental policy has significant influence on employment (Patuelli et al., 2005). For instance, a study by Caldés et al. (2009) illustrates that regulatory framework to promote renewable energies contributes to net employment. Ge and Zhi (2016) analyzed the relationship of clean energy policies in different countries. They found that green economy has positive effect on employment in both developing and developed countries. Kunapatarawong and Martínez-Ros (2016) also found a positive relationship between green innovation and employment. Various governments have already stressed sizeable job creation potential from their green growth strategies and green stimulus packages (OECD, 2011b). It is now widely accepted that green policies have positive impact on employment.

Firms of different sizes have different roles to play in industry transformations towards sustainable development. Their relative strengths and weaknesses towards sustainability are different. MSMEs and SMEs are confronted with liability of smallness (Bruderl and Schussler, 1990) and limited resources. They are also more likely to continue with their 
traditional means of production and can be quite reticent to change (OECD, 2010). At the same time, small and new firms usually display a high level of environmental performance to appeal to a niche market that is very concerned about sustainability. Attracted by early market success of as well as growing threats from these small greening firms, larger firms follow up with corporate sustainability initiatives of their own (Hockerts and Wüstenhagen, 2010). Policies with fiscal stimulus that contained significant green components targeting SMEs hold particular promise as they account for a large share of employment and employment growth in most countries (UNEP, 2011).

\subsection{Technological innovation $(R \& D \& I)$ tax credit and impact on employment}

R\&D\&I tax credit aims to stimulate firms to conduct R\&D. It is the most favorable innovation policy instrument among the OECD countries. First, volume credit of up to $25 \%$ of R\&D expenses incurred in that tax year can be obtained. Second, individuals and firms are eligible for incremental credit equals to $42 \%$ when their current year expenses exceed the average of such expenditures incurred in the preceding two tax years. Third, firms could apply for a $17 \%$ credit for wages paid to qualified researchers dedicated exclusively to R\&D. Fourth, another $8 \%$ credit could be obtained on the amount invested in tangible and intangible fixed assets, excluding real estate, that are used exclusively for qualified R\&D. Fifth, expenses incurred from research on technological innovation can receive a $12 \%$ tax credit (€1 million maximum). Sixth, tax incentives are complemented by patent box regime. Currently, patent box regime is the most beneficial within the EU (Deloitte, 2014). R\&D tax incentives are one of the most popular innovation policy tools. They reduce taxes for firms that have $R \& D$ expenditure or for firms that have income from commercializing intellectual property rights (European Commission, 2014). A drawback of R\&D tax incentives is that firms will first invest in projects with highest private, rather than social returns (Hall and Van Reenen, 2000). Results from panel data covering more than 20 years show a positive effect of innovation on employment. This is true for innovation input as well as for innovation output variables (Lachenmaier and Rottmann, 2011).

Concerning firm's response of R\&D investments to fiscal incentives, the relationship differs according to firm size (Koga, 2003). R\&D tax credits are effective especially in larger firms. R\&D in large firms are often more institutionalized with own R\&D department and research centers hiring large number of $\mathrm{R} \& \mathrm{D}$ employees on a permanent basis. As large amount of money is spent on $\mathrm{R} \& \mathrm{D}$, the amount of tax reduction is also huge, contributing to the explanation why tax credit is effective (Koga, 2003). Corchuelo Martínez-Azúa and Martínez-Ros (2008) show that though firms understand the benefits and consider applying for tax credits, there exist barriers to apply them, particularly for small firms. Lack of information, lack of resources and no clear appropriation of benefits that can be derived from innovations are obstacles justifying for the reduced applications on these tax credits for SMEs. Agrawal et al. (2014) further explain that fiscal incentives for R\&D often do not produce meaningful private response because they may have little or no tax liability, lack 
sophisticated tax-planning capabilities and lack the ability and resources to start a new line of research. However, empirical result suggests that small private firms may be more responsive to $R \& D$ tax incentives than average firms, perhaps due to liquidity constraints that limit their access to external finance (Himmelberg and Petersen, 1994). Lach (2002) showed that subsidies have significant and positive impact on company-financed R\&D for SMEs but not for larger firms. Firms with recent R\&D capital expenditures are more responsive to more generous tax incentives and that tax credit programs have a larger impact on small-firm R\&D expenditures than for large firms. Tax incentive programs shows a positive impact on R\&D wages and more R\&D contracts (Agrawal et al., 2014).

In the absence of prior literature and clear evidence of the relationship between innovation and fiscal policy and employment, we consider the relationship to be exploratory in nature and purpose our research question to explore the impact of EI and R\&D\&I tax credits on employment. In particular, we explore the EI and R\&D\&I tax credit impact on employment focusing on SMEs who represent the vast majority of organizations worldwide and who are essential in delivering growth (OECD, 2017). In this paper, we further analyze the impact by differentiating between MSMEs and SMEs and propose our research question as follows.

Research Question: The impacts of EI and R\&D\&I tax credit on employment are positive for MSMEs and SMEs.

\section{Data, measures and method}

\subsection{Background}

Spain provides an interesting context to study the dynamics of environmental tax credits. Stronger environmental policies and incentive schemes addressing wide range of environmental issues have been put in place for Spain to push forward with sustainable strategy plan. Government expenditure on environmental protection had increased approximately $75 \%$ from 2000-2010. The highest amount was spent on waste management, followed by wastewater management, biodiversity protection, pollution abatement and $R \& D$, respectively. Nevertheless, revenue from environmentally related tax as a share of GDP in Spain has declined since 2000, consistent with the trend prevalent across OECD countries. In 2012, revenue from environmentally related tax was $4.94 \%$ of total tax revenue, down from $6.54 \%$ in 2000. Spain is looking for ways to have more effective environmental tax structure (OECD, 2015).

Data from Spanish Statistical Office in Figures 2010 shows that Spain (1.35\% of GDP) still ranked below EU27 average (1.90\% of GDP) in terms of internal expenditure on R\&D. SMEs (with 10 or more employees) are responsible for more than half of corporate R\&D investment, a trend that is contrary to most other OECD countries (INE, 2010; OECD, 2015). 
This trend tends to be found in countries with relatively low corporate R\&D investments and low innovative performance (OECD, 2015). Additionally, the percentage of small firms that innovate is below average, implying a high concentration in $\mathrm{R} \& \mathrm{D}$ spending among a limited number of small firms (OECD, 2014a).

\subsection{Data and sample}

The analysis is based on corporate tax records, collected by Institute of Fiscal Studies (IEF) of the Ministry of Finance and Public Administration of Spain. The dataset contains 2008 corporate tax registration records of Spanish firms $(302,031$ statements) that opted for the Régimen Especial de Empresas de Reducida Dimensión ${ }^{1}$. It is directed at small firms, whose net turnover did not exceed $€ 8$ million during the previous tax period. We also use Sistema de Análisis de Balances Ibéricos (SABI) database from 2008-2010 to complement our dataset for variables like employment, profit, debt and revenue (Agencia Tributaria, 2008). We select several key variables (i.e., sector, year and profit) common to both dataset in order to merge IEF database and SABI database together.

The distribution of firms in the sample by sector is shown in Table 1 . There are 10 sectors as categorized by IEF: unclassified, energy and water, industry, construction and real estate services, commerce, transportation and communication, tourism, services, education and health and finance and insurance. We drop unclassified sector. We also drop firms with no employees. These are legally registered individual enterprise that is a one-man firm. Our total observation is 175,557 firms. Commerce represents the largest $(25.04 \%)$ of the population, followed by construction (24.59\%) and services (15.06\%).

Table 1

FIRM DISTRIBUTION BY SECTOR

\begin{tabular}{lc}
\hline \multicolumn{1}{c}{ Sector } & Firm distribution \\
\hline Energy and water & $0,23 \%$ \\
Industrial & $12,25 \%$ \\
Construction and real estate & $24,59 \%$ \\
Commerce & $25,04 \%$ \\
Transport and communication & $4,48 \%$ \\
Hotels and restaurants & $6,93 \%$ \\
Services & $15,06 \%$ \\
Education and health & $3,57 \%$ \\
Finance and insurance & $7,86 \%$ \\
\hline Total & $\mathbf{1 0 0}$ \\
\hline
\end{tabular}

Most firms (88\%) earn more than $€ 60,000$ during the last tax period, $40 \%$ have sales level more than $€ 60,000$ but less than $€ 300,000$ and $48 \%$ have sales level more than 
$€ 300,000$. The distribution of firms in the sample by region is shown in Figure 1. The regions that are most represented are Cataluña (20.28\%), followed by Madrid (16.86\%) and Andalucía $(15.02 \%)$. The regions that are least represented are Navarra $(0.0017 \%)$, País Vasco $(0.01 \%)$, Ceuta-Melilla (0.15\%) and La Rioja (0.70\%).

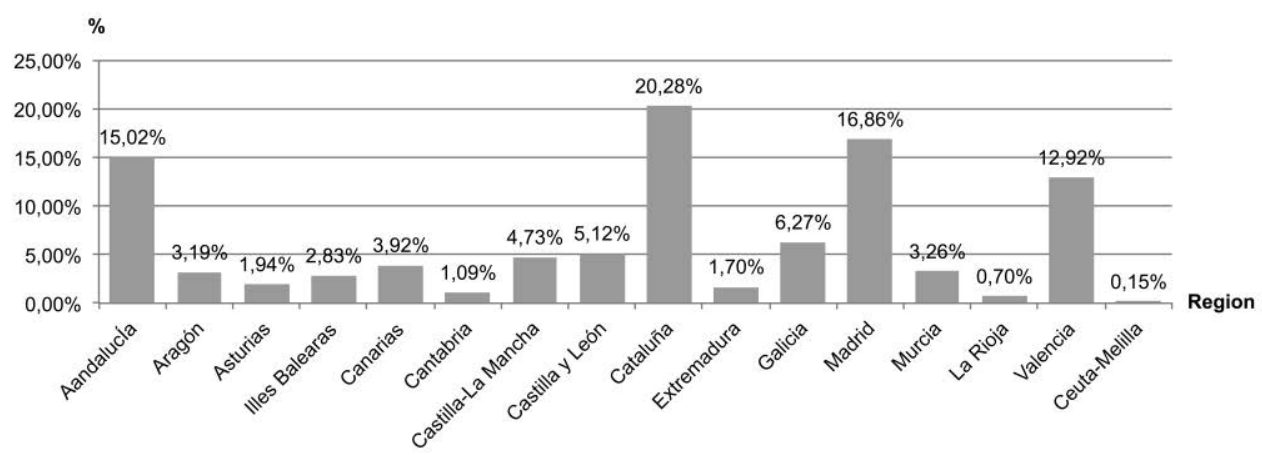

Figure 1: Firm Distribution by Region

Note: Navarra and País Vasco are dropped due to differences in tax regimes.

\subsection{Methodology}

Our model to estimate the impact of two different public incentives on the level of employment is described below. We assume that firms use both incentives in different manner when they fix their competitive strategies and these is traduced in the effect of new employees in different way, as well.

Equation 1:

Employment $_{i t}=\alpha+\beta E I$ tax credit $_{i t-2}+\gamma R \& D \&$ I tax $_{\text {credit }}{ }_{i t-2}+\delta$ Controls $_{i t}+\varepsilon_{i t}$

We use OLS to regress natural logarithm of employees in 2010 on EI and R\&D\&I tax credit dummies in 2008. We drop large firms (with more than 250 employees), as there are only 18 observations. After all, this tax record is a special regime for small firms with previous tax period not exceeding $€ 8$ million. Our dataset is cross-sectional and our dependent variable is a continuous variable. Though our dependent variable is not normally distributed, OLS remains a statistically sound technique in a study of very large sample sizes. We also use robust OLS to help control for heteroscedasticity. We explain the components of the equation as follows.

\subsection{Dependent variables}

The dependent variable is EMPLOYMENT. Based on International Labor Organization's definition, employment is referred to "a worker who holds [a] job ... who has had, 
and continues to have, an explicit or implicit contract of employment" (ILO, 1993: p. 2). To answer our research question, we follow Kunapatarawong and Martínez-Ros (2016)'s approach in using natural logarithm of total employees of firm $i$ at time $t$ as a measure of employment. The data is taken from SABI of 2010. The aim of the paper is to analyze the relationship between green innovation and employment, taking into consideration whether firms innovate or not may have influence on firms' green innovations, not how firms innovate and grow. In our analysis, we take into account a pure relationship among public incentives and employment. We study the relationship between firms that apply and receive EI and R\&D\&I tax credit and employment level, not employment creation. From our study, we cannot infer a cause-effect relationship, since we could not control for potential synergies or endogeneity problems as in the case of panel data. According to the arguments above, we do not use variable in the level of employment because we consider that firm size measured by number of employees is more stable for this short period in time with minor changes (during Spain's severe economic crisis). Hence, the use of total employment level is appropriate.

Table 2 shows the detail of the number of employees. We can see that only $0.01 \%$ are firms with more than 250 employees. After all, we use the IEF dataset that is directed at small firms with net turnover not exceeding $€ 8$ million during the previous tax period. Furthermore, SMEs usually constitute the majority of firms in industrialized-economies (Baumann and Kritikos, 2016). In this manner, the focus of this paper is on SMEs and we drop firms with more than 250 employees from our estimations. The literature further shows that MSMEs are different from SMEs, such as in terms or R\&D investment level (Cohen and Klepper, 1996), information asymmetries and credit constraints (Czarnitzki and Hottenrott, 2011). In line with the definition from the European Commission (2016) and Baumann and Kritikos (2016) in separating MSMEs from SMEs, our MSMEs are referred to firms with 1-10 employees and SMEs are referred to a firm employing 11-250 employees.

Table 2

DISTRIBUTION OF FIRMS BY NUMBER OF EMPLOYEES

\begin{tabular}{ccc}
\hline Number of employees & Number of firms & \% \\
\hline $01-10$ & 149.433 & 85,12 \\
$11-25$ & 19.537 & 11,13 \\
$26-50$ & 5.176 & 2,95 \\
$51-100$ & 1.127 & 0,64 \\
$101-250$ & 266 & 0,15 \\
More than 250 & 18 & 0,01 \\
\hline Total & $\mathbf{1 7 5 . 5 5 7}$ & $\mathbf{1 0 0}$ \\
\hline
\end{tabular}

Note: We exclude firms with no employees. 


\subsection{Explanatory variables}

The explanatory variables are EI and R\&D\&I tax credits. The data is taken from 2008 IEF corporate tax records. The EI tax credit is to help foster investments in environmental protection. The R\&D\&I tax credit is used to stimulate firms to invest in $R \& D$. We follow the approach of Busom et al. $(2014,2017)$ when constructing R\&D\&I tax credit. R\&D\&I tax credit variable has value of 1 if a firm declares having claimed R\&D\&I tax credit in 2008 and 0 otherwise. We follow the approach of Triguero et al. (2013) when constructing EI tax credit. EI tax credit variable has a value of 1 if a firm receives EI tax credit in 2008 and 0 otherwise.

From 2008 IEF dataset, the value and number of firms making use of all types of tax credits (e.g., EI, R\&D\&I) have continuously increased since 2004. The total amount of tax credits increased from $€ 14.30$ millions in 2004 to $€ 33.60$ millions in 2007 . Figure 2 shows the total number of firms that received tax credits from 2004-2007. The total number of firms with tax credits was 1,042 in 2004. The number more than doubled to 2,506 firms by 2007 . Among these firms, micro firms (1,437 firms) make use of tax credits more than SMEs (1,069 firms). However, in relative terms and considering the distribution of employment in 2008, SMEs use 4\% tax credits while MSMEs use only $1 \%$.

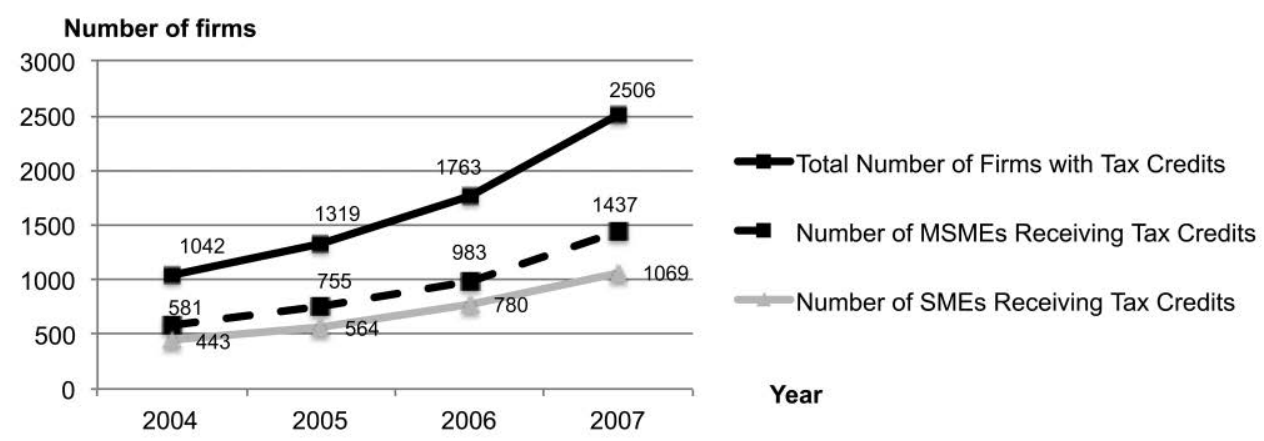

Figure 2: Total Firms Receiving Tax Credits (2004-2007)

Figure 3 and Figure 4 show variations in terms of investment in environmental protection and in R\&D\&I in different sectors. Only $0.53 \%$ of firms have investments in environmental protection and $0.38 \%$ of firms have investments in R\&D\&I in 2008. Of all the firms that invested in environmental protection, Figure 3 shows that the most prominent sector in EI tax credit is transport. This is followed by commerce sector. Tourism and education \& health sectors had low level of firms investing in environmental protection. Though transport was the most prominent in terms of EI tax credit, Figure 4 shows that R\&D\&I tax credit was very low (1.21\%). This might imply investments in end-of-the-pipe type technologies to comply with environmental regulations rather than investing in developing green innova- 
tions. Of all the firms that invested in R\&D\&I, the two sectors with the highest R\&D\&I investments were industrials $(35.30 \%)$, followed by services $(33.48 \%)$.

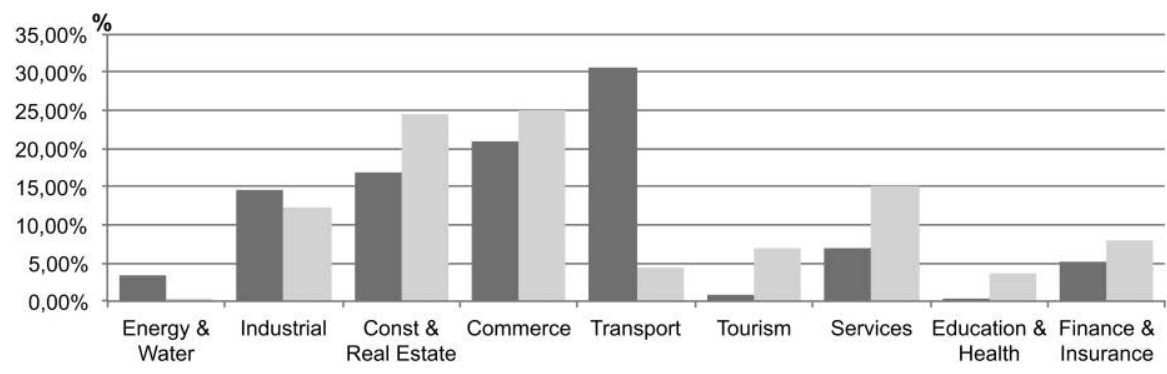

m $\%$ of Firms with Environmental Protection Investments $=\%$ of Firms without Environmental Protection Investments

Figure 3: Firms with EI Tax Credit by Sector

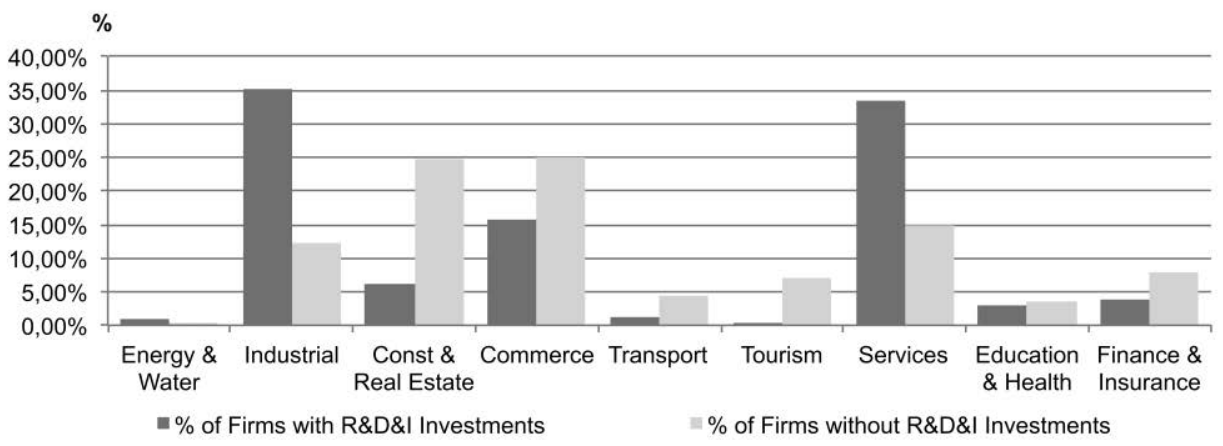

Figure 4: Firms with R\&D\&I Tax Credit by Sector

Figure 5 and Figure 6 show firms in different regions with and without EI and R\&D\&I tax credits. Among the $0.53 \%$ of firms that invested in environmental protection in 2008 , firms in Cataluña were the most active in terms of environmental protection. This is followed by Valencia and Castilla y León, respectively. Figure 6 shows that Cataluña and Madrid were the most innovative, followed by Valencia and Castilla y León. 


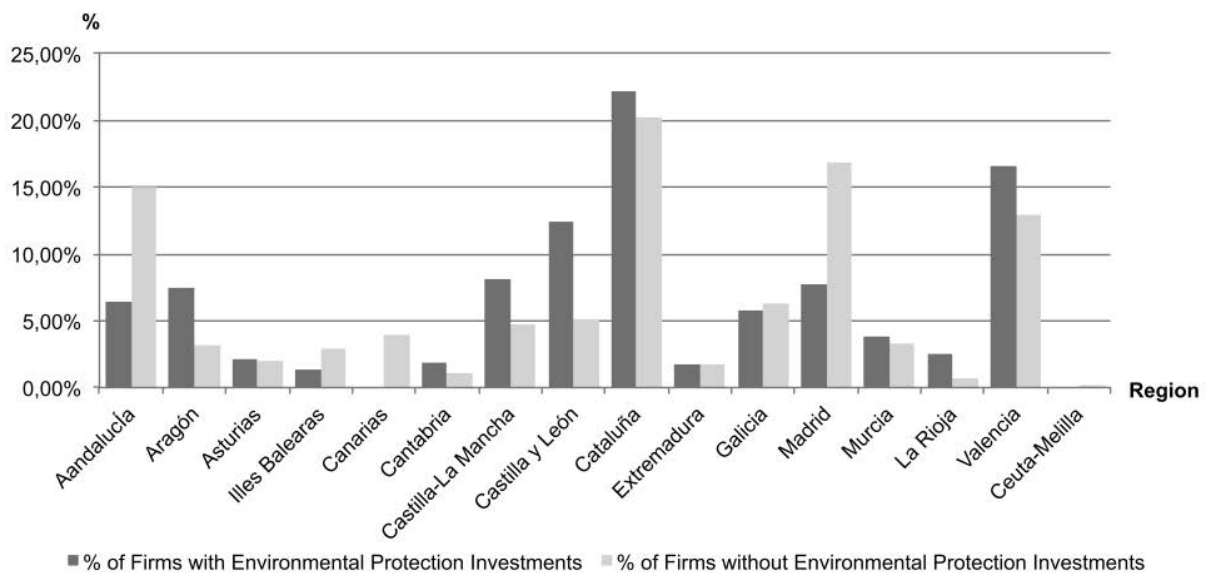

Figure 5: Firms with EI Tax Credit by Region

Note: Navarra and País Vasco are dropped due to differences in tax regimes.

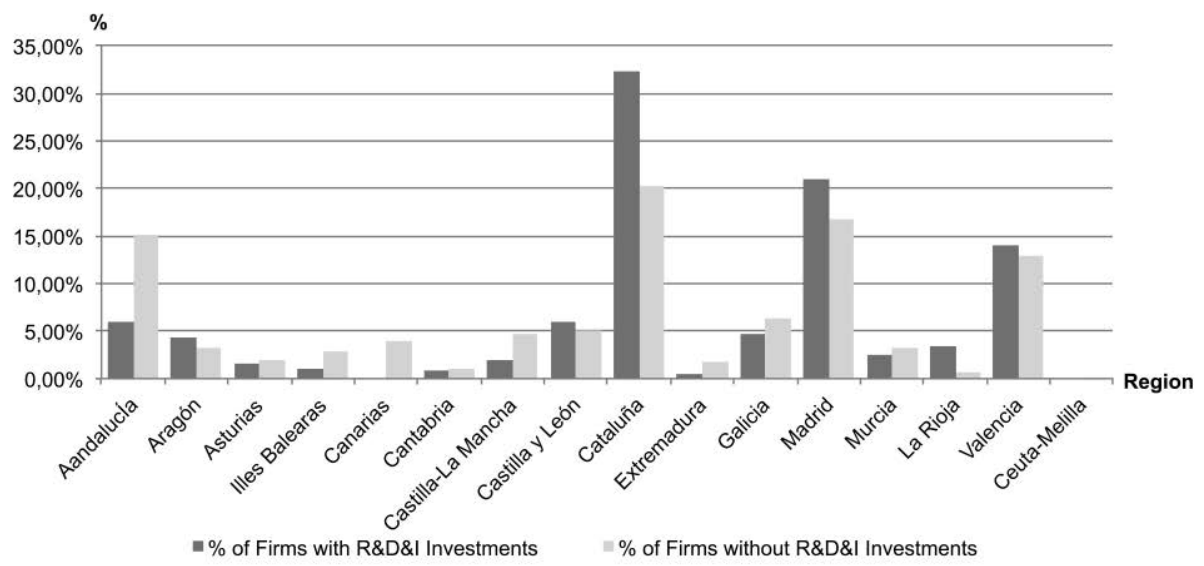

Figure 6: Firms with R\&D\&I Tax Credit by Region

Note: Navarra and País Vasco are dropped due to differences in tax regimes.

\subsection{Control variables}

From the dataset, smaller and worse-performing firms are not dedicated to environmental protection investments. Therefore, we control for whether or not firms had positive reported earnings. A firm receives a value of 1 if it had positive reported earnings and 0 otherwise. In 2008 IEF dataset, $60.44 \%$ of firms reported positive earnings. Additional control variables are included to account for possible sources of heterogeneity. They are exporter status, industry 
sector and region. All variables are defined in Table 3 and the Appendix A. Takalo et al. (2013a, b) and Huergo and Trenado (2010) show that firm's presence in export markets increases both the probability to apply for $\mathrm{R} \& \mathrm{D}$ grants and the probability to obtain support as agency is more likely to award support based on firm's technical capability and export potential. We follow Busom et al. (2014)'s approach and create a dummy of exporter status, valuing 1 if firm exports. This information is taken from SABI (2008). Sectors differ along several dimensions, e.g., and 0 otherwise, degree of market competition, technological opportunities, etc. (Castellacci and Lie, 2015). We control for industry characteristics. Dummy variables, valuing 1 if the firm belongs to a certain industry and 0 otherwise, are used. Furthermore, differences among the 18 autonomous regions of Spain impact the level of employment. For example, these are differences in the level of economic activities, business activity concentration, innovation expenditure, regulatory context, etc. We include dummies to control for regions.

Table 3

VARIABLE DEFINITION

\begin{tabular}{|c|c|}
\hline Variables & Description \\
\hline Employee & Natural logarithm of total employees of firm i \\
\hline EI tax credit (dummy) & Dummy; 1 if firm receives EI tax credit \\
\hline EI tax credit $(\log )$ & Natural logarithm of the amount of EI tax credit \\
\hline R\&D\&I tax credit (dummy) & Dummy; 1 if firm receives $R \& D \& I$ tax credit \\
\hline R\&D\&I tax credit (log) & Natural logarithm of the amount of R\&D\&I tax credit \\
\hline Positive reported earnings & Dummy; 1 if firm reports positive earnings \\
\hline Exporter & Dummy; 1 if firm exports \\
\hline Sector & $\begin{array}{l}\text { Dummy; } 9 \text { sectors } \\
\text { - Energy and water } \\
\text { - Industrial } \\
\text { - Construction and real estate } \\
\text { - Commerce } \\
\text { - Transportation and communication } \\
\text { - Tourism } \\
\text { - Services } \\
\text { - Education and health } \\
\text { - Finance and insurance }\end{array}$ \\
\hline Region & $\begin{array}{l}\text { Dummy; } 18 \text { autonomous regions in Spain } \\
\text { - Andalucía } \\
\text { - Aragón } \\
\text { - Asturias } \\
\text { - Illes Balearas } \\
\text { - Canarias } \\
\text { - Cantabria } \\
\text { - Castilla-La Mancha }\end{array}$ \\
\hline
\end{tabular}


(Continued)

\begin{tabular}{ll}
\hline Variables & Description \\
\hline Region & Castilla y León \\
& - Cataluña \\
& - Extremadura \\
& - Galicia \\
& - Madrid \\
& $\bullet$ Murcia \\
& $\bullet$ Navarra \\
& - País Vasco \\
& - La Rioja \\
& $\bullet$ Valencia \\
& $\bullet$ Ceuta-Melilla \\
\hline
\end{tabular}

\section{Results and discussion}

\subsection{Descriptive Statistics}

Correlation coefficients are shown in Appendix A. Both EI tax credit $(r=0.0704$, $\mathrm{p}<0.05)$ and $R \& D \& I$ tax credit $(r=0.0763, \mathrm{p}<0,05)$ are positively related with employment level. Positive reported earning is positively correlated with employment level $(r=0.1426$, $\mathrm{p}<0.05)$. Firms that export are also positively correlated with employment level $(r=0.0222$, $\mathrm{p}<0.05$ ). The correlations indicate a low probability of a multicollinearity problem. However, we test for multicollinearity using variance inflation factors (VIFs). Mean VIF is at 1.45. VIFs are in the range of 1.00-3.15.

Tables 4-5 show results testing our research question on the differences in firm size and its relationship to both tax credits on employment level. Table 4 reports results of baseline model for our research question on differences for MSMEs versus SMEs. In general, our result shows a positive relationship between both EI tax credits and employment for all firms (MSMEs and SMEs), Column 1-3 report results on MSMEs. Column 4-6 report results on SMEs. Column 1 and 4 report results on the relationship between EI tax credit on employment. We can see that there is a positive relationship between EI tax credit on employment and the impact of EI tax credit on employment is stronger for MSMEs than for SMEs. Column 2 and 5 report results on the relationship between R\&D\&I tax credit on employment. Again, the relationship is positive and the impact of R\&D\&I is stronger for MSMEs than for SMEs. Also, the impact of R\&D\&I on employment is greater than the impact of EI on employment for both MSMEs and SMEs. Column 3 and 6 report results testing the relationship of both EI tax credit and R\&D\&I tax credit on employment. With both tax credits combined, the relationship is positive, and the magnitude is larger for MSMEs than for SMEs. There is no significant change in the magnitude, signifying that our results are robust. We confirm our research question. 
Table 4

REGRESSION RESULTS BY FIRM SIZE-BASELINE MODEL

\begin{tabular}{|c|c|c|c|c|c|c|}
\hline & \multicolumn{3}{|c|}{ MSMEs } & \multicolumn{3}{|c|}{ SMEs } \\
\hline & (1) & (2) & (3) & (4) & (5) & (6) \\
\hline \multirow[t]{2}{*}{ EI tax credit } & $0.272 * * *$ & & $0.269 * * *$ & $0.186^{* * *}$ & & $0.178 * * *$ \\
\hline & $(0.023)$ & & $(0.023)$ & $(0.024)$ & & $(0.024)$ \\
\hline \multirow[t]{2}{*}{ R\&D\&I tax credit } & & $0.310 * * *$ & $0.306^{* * *}$ & & $0.256^{* * * *}$ & $0.250 * * *$ \\
\hline & & $(0.030)$ & $(0.030)$ & & $(0.029)$ & $(0.029)$ \\
\hline \multicolumn{7}{|l|}{ Controls: } \\
\hline \multirow[t]{2}{*}{ Positive reported earnings } & $0.129^{* * * *}$ & $0.130^{* * *}$ & $0.129^{* * * *}$ & $0.032^{* * *}$ & $0.032^{* * * *}$ & $0.029^{* * * *}$ \\
\hline & $(0.003)$ & $(0.003)$ & $(0.003)$ & $(0.007)$ & $(0.007)$ & $(0.007)$ \\
\hline \multirow[t]{2}{*}{ Exporters } & $0.416^{* * *}$ & $0.405^{* * *}$ & $0.406^{* * *}$ & 0.011 & 0.014 & 0.012 \\
\hline & $(0.090)$ & $(0.089)$ & $(0.089)$ & $(0.071)$ & $(0.073)$ & $(0.071)$ \\
\hline Regions & Yes & Yes & Yes & Yes & Yes & Yes \\
\hline Sectors & Yes & Yes & Yes & Yes & Yes & Yes \\
\hline \multirow[t]{2}{*}{ Constant } & $1.057 * * *$ & $1.075^{* * *}$ & $1.053 * * *$ & $3.051^{* * *}$ & $3.053 * * *$ & $3.048 * * *$ \\
\hline & $(0.028)$ & $(0.028)$ & $(0.028)$ & $(0.085)$ & $(0.084)$ & $(0.083)$ \\
\hline $\mathrm{N}$ & 149,433 & 149,433 & 149,433 & 26,106 & 26,106 & 26,106 \\
\hline $\mathrm{R}^{2}$ & 0.038 & 0.038 & 0.038 & 0.031 & 0.032 & 0.034 \\
\hline
\end{tabular}

Note: Standard errors in parentheses: $* * *<<0.01$.

We also provide results testing the joint effect of both types of tax credits with interactions in Table 5. Column 1 and 4 report results with interactions of both tax credits. Column 2 and 5 report results of interactions of EI and R\&D\&I tax credit with positive reported earnings. Column 3 and 6 report results of interactions of EI and R\&D\&I tax credit with positive reported earnings. Results show that the impact of both tax credits on employment are independent of each other for both MSMEs and SMEs. We can see that results for SMEs are of the same pattern as for MSMEs, except for the interactions of EI and R\&D\&I tax credit with exporters. In SMEs, exporters appear to be greener, using tax credit as a form to alleviate the cost of their eco-investments increasing the impact on employment. However, it seems that exporters do not use innovation tax credit as a profitable tool, using them as a form to downsize the company.

Table 5

\section{REGRESSION RESULTS WITH INTERACTIONS}

MSMES

(1)

(2)
EI tax credit
(3)

\section{SMEs}

(5)

(6)
(4) 


\begin{tabular}{|c|c|c|c|c|c|c|}
\hline & \multicolumn{3}{|c|}{ MSMEs } & \multicolumn{3}{|c|}{ SMEs } \\
\hline & (1) & (2) & (3) & (4) & (5) & (6) \\
\hline & $(0.024)$ & $(0.048)$ & $(0.023)$ & $(0.024)$ & $(0.061)$ & $(0.024)$ \\
\hline R\&D\&I tax credit & $\begin{array}{l}0.306^{* * *} \\
(0.030)\end{array}$ & $\begin{array}{l}0.306 * * * \\
(0.061)\end{array}$ & $\begin{array}{l}0.306 * * * \\
(0.030)\end{array}$ & $\begin{array}{l}0.250 * * * \\
(0.029)\end{array}$ & $\begin{array}{l}0.247 * * * \\
(0.084)\end{array}$ & $\begin{array}{l}0.250 * * * \\
(0.029)\end{array}$ \\
\hline Positive reported earnings & $\begin{array}{l}0.129 * * * \\
(0.003)\end{array}$ & $\begin{array}{l}0.129 * * * \\
(0.003)\end{array}$ & $\begin{array}{l}0.129 * * * \\
(0.003)\end{array}$ & $\begin{array}{l}0.029 * * * \\
(0.007)\end{array}$ & $\begin{array}{l}0.030 * * * \\
(0.007)\end{array}$ & $\begin{array}{l}0.029 * * * \\
(0.007)\end{array}$ \\
\hline Exporters & $\begin{array}{l}0.406^{* * *} \\
(0.089)\end{array}$ & $\begin{array}{l}0.406^{* * *} \\
(0.089)\end{array}$ & $\begin{array}{l}0.408 * * * \\
(0.093)\end{array}$ & $\begin{array}{l}0.011 \\
(0.071)\end{array}$ & $\begin{array}{l}0.012 \\
(0.071)\end{array}$ & $\begin{array}{l}-0.003 \\
(0.072)\end{array}$ \\
\hline EI tax credit \# R\&D\&I tax credit & $\begin{array}{l}0.008 \\
(0.159)\end{array}$ & & & $\begin{array}{l}-0.002 \\
(0.166)\end{array}$ & & \\
\hline $\begin{array}{l}\text { EI tax credit \# Positive reported } \\
\text { earnings }\end{array}$ & & $\begin{array}{l}-0.035 \\
(0.055)\end{array}$ & & & $\begin{array}{l}-0.084 \\
(0.066)\end{array}$ & \\
\hline $\begin{array}{l}\text { R\&D\&I tax credit \# Positive } \\
\text { reported earnings }\end{array}$ & & $\begin{array}{l}-0,001 \\
(0.070)\end{array}$ & & & $\begin{array}{l}0.003 \\
(0.090)\end{array}$ & \\
\hline EI tax credit \# exporters & & & $\begin{array}{l}0.000 \\
(0.000)\end{array}$ & & & $\begin{array}{l}0.694 * * * \\
(0.076)\end{array}$ \\
\hline $\mathrm{R} \& \mathrm{D} \& \mathrm{I}$ tax credit \# exporters & & & $\begin{array}{l}-0.061 \\
(0.097)\end{array}$ & & & $\begin{array}{l}-0.207^{* * *} \\
(0.078)\end{array}$ \\
\hline Regions & Yes & Yes & Yes & Yes & Yes & Yes \\
\hline Sectors & Yes & Yes & Yes & Yes & Yes & Yes \\
\hline Interaction with regions & Yes & Yes & Yes & Yes & Yes & Yes \\
\hline Interaction with sector & Yes & Yes & Yes & Yes & Yes & Yes \\
\hline Constant & $\begin{array}{l}1.053^{* * *} \\
(0.028)\end{array}$ & $\begin{array}{l}1.053 * * * \\
(0.028)\end{array}$ & $\begin{array}{l}1.053 * * * \\
(0.028)\end{array}$ & $\begin{array}{l}3.048 * * * \\
(0.082)\end{array}$ & $\begin{array}{l}3.048 * * * \\
(0.082)\end{array}$ & $\begin{array}{l}3.048 * * * \\
(0.082)\end{array}$ \\
\hline $\mathrm{N}$ & 149,433 & 149,433 & 149,433 & 26,106 & 26,106 & 26,106 \\
\hline $\mathrm{R}^{2}$ & 0.038 & 0.038 & 0.038 & 0.034 & 0.034 & 0.034 \\
\hline
\end{tabular}

Note: Standard errors in parentheses: $* * *<<0.01$.

Table 6 shows robustness check and expand the results. A different specification of explanatory variable is used. Instead of dummies, we use natural log of EI and R\&D\&I tax credit amount. With a log-log specification (Column 1-2), we can obtain results in terms of elasticity, which is a more accurate measure of the sensibility of employment versus public incentives. In addition, we try a different specification of dependent variable. Instead of a natural logarithm of total employees of firm i at time t, we use employment growth. Results show that EI and R\&D\&I tax credit do not have impact on the growth of employment in the 
period studied. This is understandable because Spain experienced severe economic crisis during 2008-2010, with significant downsizing across the sectors. The impact may be null or too small to be significant.

Table 6

ROBUSTNESS CHECKS

\begin{tabular}{|c|c|c|c|c|}
\hline & \multicolumn{2}{|c|}{ Ln(Employment) } & \multicolumn{2}{|c|}{ Employment Growth } \\
\hline & MSMEs & SMEs & MSMEs & SMEs \\
\hline & (1) & (2) & (3) & (4) \\
\hline \multirow[t]{2}{*}{ EI tax credit } & & & -0.003 & 0.038 \\
\hline & & & $(0.005)$ & $(0.031)$ \\
\hline \multirow[t]{2}{*}{ R\&D\&I tax credit } & & & 0.007 & 0.017 \\
\hline & & & $(0.006)$ & $(0.013)$ \\
\hline \multirow[t]{2}{*}{$\log (\mathrm{EI}$ tax credit $)$} & $0.027 * * *$ & $0.022 * * *$ & & \\
\hline & $(0.003)$ & $(0.003)$ & & \\
\hline \multirow[t]{2}{*}{$\log (R \& D \& I$ tax credit $)$} & $0.038 * * *$ & $0.028 * * *$ & & \\
\hline & $(0.003)$ & $(0.003)$ & & \\
\hline \multirow[t]{2}{*}{ Positive reported earnings } & $0.129 * * *$ & $0.029 * * *$ & 0.001 & -0.005 \\
\hline & $(0.003)$ & $(0.007)$ & $(0.001)$ & $(0.005)$ \\
\hline \multirow[t]{2}{*}{ Exporters } & $0.403^{* * *}$ & 0.017 & -0.378 & -0.903 \\
\hline & $(0.090)$ & $(0.072)$ & $(0.591)$ & $(0.843)$ \\
\hline Regions & Yes & Yes & Yes & Yes \\
\hline Sectors & Yes & Yes & Yes & Yes \\
\hline \multirow[t]{2}{*}{ Constant } & $1.015^{* * *}$ & $3.020 * * *$ & -0.002 & -0.008 \\
\hline & $(0.028)$ & $(0.083)$ & $(0.001)$ & $(0.010)$ \\
\hline $\mathrm{N}$ & 149,433 & 26,106 & 149,433 & 26,106 \\
\hline $\mathrm{R}^{2}$ & 0.038 & 0.035 & 0.002 & 0.009 \\
\hline
\end{tabular}

Note: Standard errors in parentheses. $* * *<<0.01$.

\subsection{Discussion}

Green policies and incentives are drivers and shapers for sustainable development through a refocus on better management of our common wealth and natural resources (Guo et al., 2017; Porter \& van der Linde, 1995; Veugelers, 2012). Kemp (2000) argues that environmental regulations are valuable because they provide both informative and normative content, in the sense that the demand for a greener environment is translated into specific policies where strict guidelines 
are given so green innovators understand the direction and what is required of them. Environmental regulations help provide the focus as well as influence the pace so firms can make choices based on their competitive position and the world around them, rather than having to try to innovate in many directions at once (Rennings and Rammer, 2011).

Results from Table 4 show a positive relationship between EI tax credit and employment for MSMEs and SMEs. The arguments in favor would say that green fiscal stimuli create jobs and lay a strong foundation for a more sustainable growth. This aligns with the double dividend hypothesis (Goulder, 1995). The first benefit is called the green dividend that helps to preserve the environment. The second benefit is called the blue dividend or additional positive effects (Cansino et al., 2010). In this case, revenue from pollution taxes (green dividend) can be used to compensate for loss in government's income from providing EI tax credits to firms, helping to reduce distortions on corporate income, which in turn, provides a societal benefit through employment (blue dividend). The arguments against would say there is a trade-off between greenness and employment. Nevertheless, prior studies find only small effect. The effects appear to be positive in more efficient firms and adverse for less efficient firms. Moreover, the effects vary widely across regions and sectors. For instance, a negative relationship is found for sectors that are subject to more stringent environmental regulations (OECD, 2014b).

Results must be carefully interpreted. Net changes in employment depend not only on green policies, but also on how labor market functions (OECD, 2014b). First, positive impact on labor market can be influenced by how revenues from other environmental taxes are used (Bowen, 2012). Second, in 2011, the Law on Sustainable Economy fixed EI tax credit rate at 8\%, resulting in smaller number of firms that applied. That year, 744 entities were eligible, but only 359 entities applied (Magrama, 2013). Puig Ventosa (2010)'s study on Spanish EI tax credit finds that expenditure on cleaner production (as opposed to end-of-pipe expenditures) is lower than other types of environmental investments. The present weight of end-of-pipe technologies investments taking benefit of EI tax credit suggests a limited incidence of EI tax credit for green innovation, since green innovation is identified with cleaner production. This implies that EI has no or low impact on activating green innovation. In 2014, EI tax credit was repealed (OECD, 2015).

Magrama (2013) shows that firms rely greatly on government supports for green investments. Busom et al. (2014) find that financial constraints to conduct innovative projects and appropriability of returns are correlated with firms' access to R\&D subsidies and R\&D tax credits. For both SMEs and large firms, financial constraints are found to increase the probability of obtaining $R \& D$ subsidies but decrease probability of claiming $R \& D$ tax credits.Is the elimination of EI tax credit a good decision? Various limitations of Spain's EI tax credit have been found to include complex processes, inflexible mechanisms, policy discontinuities and changes in legal framework, posting costs to firms. A positive tax payable was necessary to receive tax credits. Further, many firms were unaware, leading to limited use (Puig Ventosa, 2010). If EI tax credit was truly environmentally harmful and economically inefficient, the repeal was necessary. Then again, a positive relationship between EI tax credit and employment is found in this study. Should EI tax deduction be re-enacted with more efficient mechanisms or should green fiscal stimuli in other forms (e.g., subsidies) be used to give incentives to firms that are trying to go green or develop green innovation? 
Our results from Table 4 show a positive relationship between R\&D\&I tax credit and employment for MSMEs and SMEs, consistent with prior studies (Lachenmaier and Rottmann, 2011). Our results show that the impact is stronger for MSMEs. Tax incentive is an important policy tool for supporting private $R \& D$. A result from meta-regression analysis between 1990-2013 shows that R\&D tax credit is the main public policy instrument used to help increase private firms' incentives to invest in R\&D activities (Castellacci and Lie, 2015). This may be the reason why R\&D tax incentives are often designed to offer a more generous tax advantage to young and small firms via the mechanism of setting up overall maximum amount that can be claimed. Since smaller firms typically have smaller budgets, it is likely that small firms can claim the full benefit (European Commission, 2015).

This work presents us with several limitations. First, we do not assess overall net impact on employment. Green policies affect labor markets directly and indirectly. A creative destruction (i.e., destruction of brown jobs in polluting industries) is necessary to achieve green growth (OECD, 2011b) or how green policies create new green competitive niches. A study on net effect on employment would help policy makers design green policies that promote a smooth and just transition towards being green. To assess how aggregate labor market works as a whole and to assess overall effects of green policies on employment, it is crucial to understand the characteristics of the economy's labor markets, how macro economy works and the nature of the policy interventions. The use of a panel data would help to address this limitation. Unemployment indeed occurs due to multiple causes. The consequences of green policies will differ depending on these causes. Future research can address this limitation by focusing on labor market adjustments in different types of economy (Bowen, 2012). The intensity of environmental regulations are different for different regions and the level of eco-efficiency is also different in different region (Ren et al., 2018). It would also be interesting to study the impacts on different regions as well as sectors. Future research addressing ex ante and ex post analysis of green policies on employment or other social and technological impacts is also valuable.

Second, we do not assess the impact on employment based on skill set or skill level of labor (i.e., low- or high-skilled labor) due to unavailability of data. Future research that can address this gap is needed. This matters because prior studies show a positive impact in employment for some specialized skills or highly skilled labor (OECD, 2014b). Furthermore, future research can study to what extent the skill set in the labor force is being altered. If certain required skill sets were unavailable, this would place a major obstacle towards green growth. Policy makers need to also worry about unavailable skill sets that can limit job creation (Bowen, 2012). The result from such studies will help the government with the design of a more appropriate employment protection programs (e.g., unemployment insurance, etc.) and supply-side policy elements (e.g., skill development system) that reinforce adaptive capacity of labor markets, facilitating quick re-integration of job seekers into employment (OECD, 2011b).

\section{Conclusion}

We can draw the conclusion that EI and R\&D\&I tax incentives are clearly important and needed. First, private sector is responsive to EI and R\&D\&I tax credits. Technological 
change does not exist in a vacuum (Jaffe et al., 2005). Firms rely greatly on government supports for green investments and innovations (Magrama, 2013; OECD, 2015). Public policy plays an important role in helping to incentivize firms through the use of both "carrots" (e.g., subsidies) as well as "sticks" (environmental regulations). Second, there is a positive relationship between EI and R\&D\&I tax credit and employment. Third, tax credit entails less administrative costs than subsidies. Lastly, private firms can decide whether to make use of the tax credit. Qualified application is simply automatically granted tax credits. As such, tax credit is a form of public support that distorts markets the least.

Then, how can we have tax incentives producing substantial positive implications on the society and how rapidly and deeply they will diffuse? It is difficult to measure the success of a policy. The data on private sector $R \& D$ is generally not available and the data is often disaggregated. Making linkages between R\&D data and environmentally related taxation is difficult (OECD, 2010). Output is often intangible and the expected benefits change with changing conditions. Moreover, laws and policies cannot keep pace with technological developments. The gaps are getting wider in all technological domains. Policy failures can be expected. A great number of observations at a micro-level data is ultimately required to confirm the results of a policy. The evaluation period must take place over a long-term period. Despite the complication in measuring policy impacts, the danger of not attempting to evaluate policies consigns policies forever to the realm of ideology (Jaffe et al., 2005).

Even though a body of research (e.g., Hall et al., 2010, Hall and Lerner, 2010) provides a solid ground for designing appropriate policies to support innovation, successful implementation is not an easy task largely due to imperfect and asymmetric information, resulting in unintended mistakes in policy design and implementation. An efficient allocation of support requires two conditions: (1) sufficient information to identify R\&D projects that are desirable for the society but generate low private returns or suffer from obtaining private funding and, (2) ability to match support to relevant project features (Haapanen et al., 2014).

Policy implications are that green regulations alone do not play a major role in strategic innovative decisions of the firms (Buysse and Verbeke, 2003; Aragon-Correa and LópezRubio, 2007; Nidumolu et al., 2009). It is important to understand the inner workings (e.g., motivations) of those firms that venture to make green innovations when designing green policies. Tax credit mechanisms must be designed and implemented in a way to induce maximum positive socio-economic impact, whether temporary or more permanent, while ensuring fiscal sustainability. We include some relevant ideas (e.g., Bowen, 2012; CPB, 2014; OECD, 2015) for EI and R\&D\&I tax credit as follow.

First, there must be a fair and efficient tax collection system. Second, design the use of green taxes in the framework of a comprehensive tax reform to receive double dividend. Focus on growth-enhancing investments with clearly identified and measurable indicators and objectives that also meet larger, national- or regional-level green goals (CPB, 2014; OECD, 2015). 
Third, stimulate EI and R\&D\&I tax incentive schemes together. A study by Puig Ventosa (2010) shows a positive environmental consequence of R\&D\&I tax credit. R\&D\&I by private firms in Spain is higher than the percentage of R\&D expenditures dedicated to environmental control and protection, suggesting a positive environmental bias in innovation activities that receive public financial support. The application of R\&D\&I tax credit increased the application of EI tax credits in subsequent years, indicating a move towards green innovation. Ploeg and Withagen (2013) show that the combination of R\&D incentive scheme (R\&D subsidies) and green incentive scheme (carbon tax) is the best way to achieve green growth. Green product innovations have positive effect on probability of employment increase (Rennings et al., 2004). A study by Kunapatarawong and Martínez-Ros (2016) shows a positive relationship between green innovation and employment. Further, a study by Jaffe et al. (2005) explains that green policies alone will not create sufficient incentives if such policies fail to fully internalize environmental externalities. Efficiency of green policy depends on its consequences for technological change, while at the same time, green policy plays a role to stimulate environmentally beneficial technological change. There is a strong interplay between technology and environment. Make sure R\&D\&I tax incentive schemes are linked to $R \& D \& I$ input (e.g., expenditure) rather than output (e.g., income made from intellectual property). To increase effectiveness of the policy, tax relief can be granted on R\&D\&I expenditure that creates significant knowledge spillovers and with stricter novelty requirements $(\mathrm{CPB}, 2014)$. Direct R\&D\&I tax incentive supports at young firms and SMEs. They are the ones who can challenge incumbent businesses and they can also generate proportionally more jobs (Criscuolo et al., 2014). Ensure that tax instruments reach the right target and not to repeated participants who might not produce genuine innovating projects with high spillover potential (Busom et al., 2017). Moreover, regulations that are clearly stated and straightforward are best at stimulating green innovations, while unclear and overly detailed regulations are barriers to innovation (Triguero et al., 2013).

Fourth, design policies that reflect variations. There is no perfect tax incentive that can be applied in all situations. Sectors and regions differ along several dimensions, such as the degree of market competition, technological opportunities, specificities of the innovation system or even varying levels of complexity of different countries' rules and administrative burden they create. Policy makers need to take into considerations context firms face and many characteristics of firms, particularly firm size. The design of policy incentives should also be specific, rather than very generic, focusing on and targeting at identifying firms that are more proactive to be green and innovative. Promote debate among all stakeholders involved to discover needs and strengthen co-operation to ensure policies best fit to different contexts (CPB, 2014; OECD, 2015).

Fifth, enhance markets and facilitate wider commercial applications for green products, services and innovations. Generation of higher level of awareness, public support and demand-side measures (e.g., green public procurement requirements, green innovationoriented standards) are needed (OECD, 2015). Reform inclusion criteria for EI eligibility, such as the requirement to efficiently use raw material or cleaner production, must be improved (Puig Ventosa, 2010). Green standards and regulations are often based on avail- 
able technologies, innovation required to just fulfill legislation is thus relatively moderate. If firms go beyond legal obligations and are still eligible for EI, such investments would help to reduce cost (via EI tax credits), which tends to favor clean production and; therefore, green innovation.

Lastly, simplify administrative procedures. Strengthen the co-ordination and procedures between central and local government to distribute support. Frequent changes should be avoided (CPB, 2014; OECD, 2015). Policy discontinuities and changes discourage Spanish firms to apply for tax credits. Evaluate regularly for progress and adjust accordingly to ensure that public funds are put to good use and they are delivering results. Support tools and benchmarking performance are necessary. Conduct independent assessment to identify ways green policies could be improved (CPB, 2014; OECD, 2015).

The environmental and social challenges are closely entwined. The world does not have enough money, resources or time to deal with them separately or consecutively (Poschen and Renner, 2015). Such challenges could be alleviated with greater use and effectiveness of green incentive schemes such as EI and R\&D\&I tax credits.

To the best of our knowledge, this study is the first to empirically explore such question. There are cases where policy creates jobs and other circumstances when it destroys jobs. We contribute to the literature by analyzing the impacts of two different public instruments (EI and R\&D\&I tax credits) on employment level for firms of different sizes, focusing on MSMEs and SMEs, where they are considered the backbone of an economy. Furthermore, we help contribute by further analyzing the joint impacts of these two tax credits on employment.

Our empirical study based on employment data from corporate tax data for MSMEs and SMEs in 2008 confirms a positive impact of green policies. A positive relationship between EI and R\&D\&I tax credits and employment is found for both MSMEs and SMEs. Our results show that the impact on employment is stronger for MSMEs than for SMEs. The impact of R\&D\&I tax credit on employment is stronger than the impact of EI tax credit for both MSMEs and SMEs. When testing for joint effect, results show that that the impact of both tax credits on employment are independent of each other for both MSMEs and SMEs.

However, we must keep in mind that green policies are no substitute for sound labor markets. Green policies will not single-handedly solve any countries' employment problems (Bowen, 2012). The important thing is the government must remain engaged in green and technology policies. Such policies must be designed and implemented in a way that they will produce net positive social returns. Additionally, policy makers must invest in human capital to deal with structural changes in the labor market, i.e., tackling potential skill shortages, impediments to workers, employment protection programs and necessary supply-side employment policy elements, to reinforce adaptive capacity of labor markets for green growth. The bottom line is that green provisions help contribute to long-term sustainability through economic activities and jobs. The world needs green growth. 


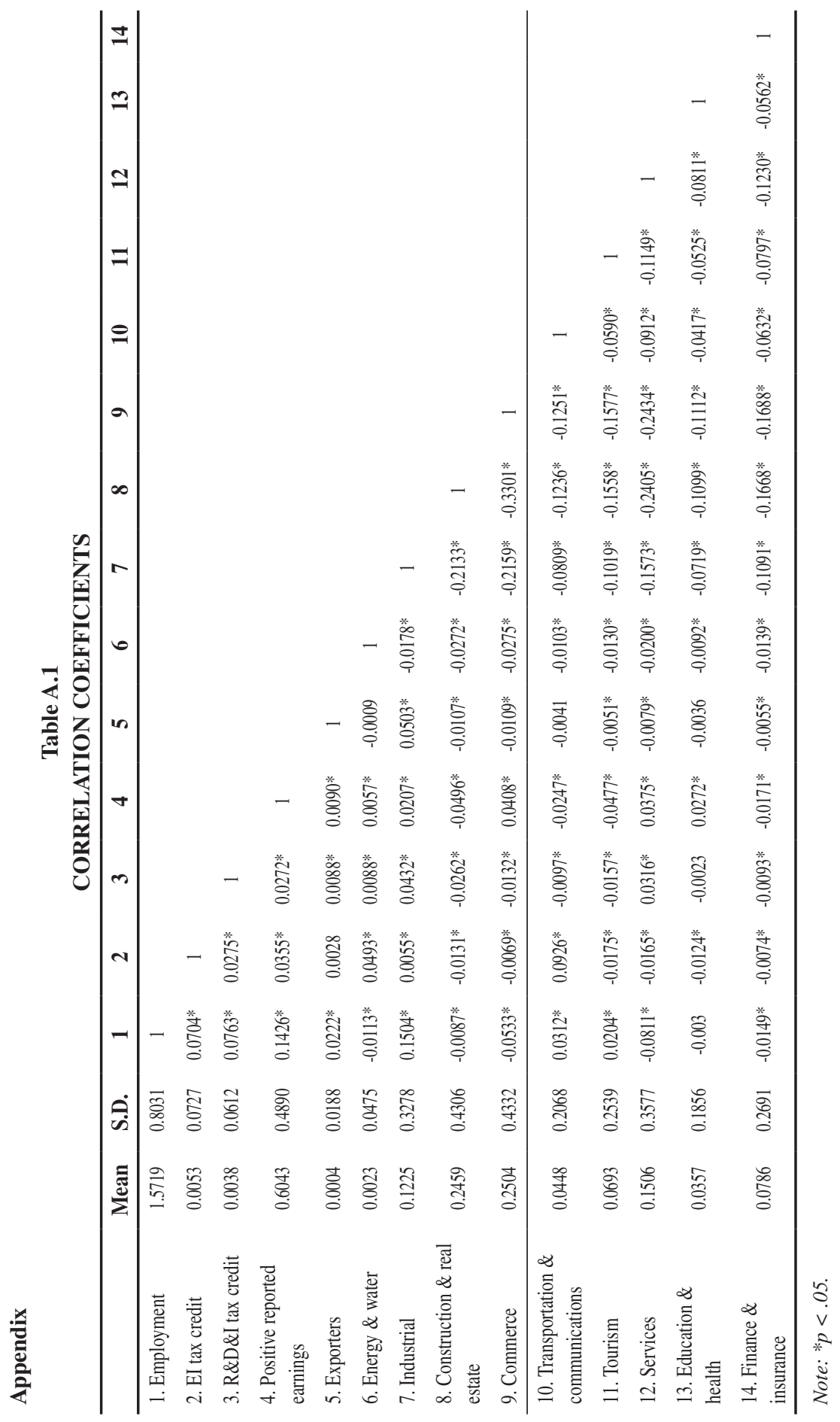




\section{Note}

1. The Special Regime is for small firm size whose net turnover in the previous tax period not exceeding 8 million euros (art. 108 LIS).

\section{References}

Acs, Z. J. and Audretsch, D. B. (1987), "Innovation, market structure and firm size", The Review of Economics and Statistics, 1987: 567-574.

Agencia Tributaria (2008), Manual práctico. Sociedades 2008, Ministerio de Economía y Hacienda, España.

Agrawal, A., Rosell, C. and Simcoe, T. S. (2014), "Do tax credits affect R\&D expenditures by small firms? Evidence from Canada", National Bureau of Economic Research, NBER Working Paper 20615.

Anger, N. and Oberndorfer U. (2008), "Firm performance and employment in the EU emissions trading scheme: An empirical assessment for Germany”, Energy Policy, 36: 12-22.

Aragon-Correa, J. A. and Rubio-López, E. A. (2007), "Proactive corporate environmental strategies: myths and misunderstandings", Long Range Planning, 40: 357-381.

Arimura, T. H., Hibiki, A. and Katayama, H. (2008), "Is a voluntary approach an effective environmental policy instrument? A case for environmental management systems", Journal of Environmental Economics and Management, 55(3) 281-295.

Baumann, J. and Kritikos, A. S. (2016), "The link between R\&D, innovation and productivity: Are micro firms different?", Research Policy, 45(6): 1263-1274.

Bloom, N., Rachel, G. and van Reenen, J. (2002), "Do R\&D tax credits work? Evidence from a panel of countries 1979-1997”, Journal of Public Economics, 85(1): 1-31.

Bowen. A. (2012), "Green growth, green jobs and labor markets", Policy Research Working Paper 5990, Washington, D.C.: World Bank.

Bruderl, J. and Schussler, R. (1990), "Organizational mortality: The liabilities of newness and adolescence", Administrative Science Quarterly, 35: 530-547.

Busom, I., Corchuelo, B. and Martínez-Ros, E. (2014), “Tax incentives.... or subsidies for business R\&D”, Small Business Economics, 43: 571-596.

Busom, I., Corchuelo, B. and Martínez-Ros, E. (2017), "Participation inertia in R\&D tax incentive and subsidy programs”, Small Business Economics, 28(1): 153-177.

Buysse, K. and Verbeke, A. (2003), "Proactive environmental strategies: a stakeholder management perspective”, Strategic Management Journal, 24: 453-470.

Caldés, N., Varela, M., Santamaría, M. and Sáez, R. (2009), "Economic impact of solar thermal electricity deployment in Spain”, Energy Policy, 37: 1628-1636.

Cansino, J. M., Pablo-Romero, M. P. and Rocío Yñiguez, R. (2010), “Tax incentives to promote green electricity: An overview of EU-27 countries", Energy Policy, 38: 6000-6008. 
Castellacci, F. and Lie, C. M. (2015), "Do the effects of R\&D tax credits vary across industries? A meta-regression analysis”, Research Policy, 44: 819-832.

Cohen, W. M. and Klepper, S. (1996), "Firm size and the nature of innovation within industries: the case of process and product R\&D", Review of Economics and Statistics, 78 (2): 232-243.

Corchuelo Martínez-Azúa, M.B. and Martínez-Ros, E. (2008), “Aplicación de los incentivos fiscales a la inversion I+D en las empresas españolas", Hacienda Pública Española, 187(4): 9-39.

CPB (2014), A study on R\&D tax incentives. Final report, Taxation Working Paper 52, The study commissioned by the European Commission.

Criscuolo, C., Gal. P. and Menon, C. (2014), "The dynamics of employment growth. New evidence from 18 countries", OECD Science, Technology and Industry Policy Papers, 14: 1-95. Paris: OECD Publishing.

Czarnitzki, D. and Hottenrott, H. (2011), "R\&D investment and financing constraints of small and medium-sized firms", Small Business Economics, 36(1): 65-83.

Damanpour, F. (1992), “Organizational size and innovation”, Organization Studies, 13: 375.

Del Río, P., Peñasco, C. and Romero-Jordán, D. (2013), "Distinctive features of environmental innovators: an econometric analysis", Business Strategy and the Environment, 24(6): 361-385.

Dechezleprêtre, A., Einiö, E., Martin, R., Nguyen, K. T. and Van Reenen, J. (2016), “Do tax incentives for research increase firm innovation? An RD design for R\&D", National Bureau of Economic Research, No. w22405.

Deloitte (2014), 2014 Global Survey of R\&D Tax Incentives, Deloitte Touche Tohmatsu Limited. http:// taxsummaries.pwc.com/uk/taxsummaries/wwts.nsf/ID/Spain-Corporate-Tax-credits-and-incentives. [1st December 2015].

Doran, J. and Ryan, G. (2016), "The importance of the diverse drivers and types of environmental innovation for firm performance", Business Strategy and the Environment, 25: 102-119.

European Commission (2003), Raising EU R\&D Intensity. Improving the Effectiveness of Public Support Mechanism for Private Sector Research and Development: Fiscal Measures, EUR 20714, DG for Research Knowledge Based Society and Economy Strategy and Policy. Investment in Research, Luxemburg.

European Commission (2014), Research and Innovation Performance in the EU: Innovation Union Progress at Country Level 2014, Luxembourg: Publications Office of the European Union.

European Commission (2015), Tax Reforms in EU Member States 2015, Tax Policy Challenges for Economic Growth and Fiscal Sustainability, Institutional Paper 008. Luxembourg: Publications Office of the European Union.

European Commission (2016), User Guide to the SME Definition, Ref. Ares (2016)956541 24/02/2016, Luxembourg: Publications Office of the European Union.

Ge, Y. and Zhi, Q. (2016), "Literature review: The green economy, clean energy policy and employment”, Energy Procedia, 88: 257-264.

Gerstlberger, W., Præst Knudsen, M. and Stampe, I. (2013), "Sustainable development strategies for product innovation and energy efficiency", Business Strategy and the Environment, 23: 131-144. 
Goulder, L. H. (1995), "Environmental taxation and the double dividend: A reader's guide", International Tax and Public Finance, 2: 1155-182.

Gunderson, R. and Yun, S. J. (2017), "South Korean green growth and the Jevons paradox: an assessment with democratic and edgrowth policy recommendations", Journal of Cleaner Production, 144: 239-247.

Guo, L. L., Qu, Y. and Tsent, M.-L. (2017), “The interaction effects of environmental regulation and technological innovation on regional green growth performance", Journal of Cleaner Production, 162: 894-902.

Hall, B. and Lerner, J. (2010), "Financing R\&D and innovation, Chapter 14.” In B.H. Hall and N. Rosenberg (eds.), Handbook of the economics of innovation, Amsterdam: Elsevier, 609-639.

Hall, B. and van Reenen, J. (2000), "How effective are fiscal incentives for R\&D? A review of the evidence", Research Policy, 29: 449-469.

Haapanen, M., Lenihan, H. and Mariani, M. (2014), “Government policy failure in public support for research and development”, Policy Studies, 35(6): 557-575.

Himmelberg, C. P. and Petersen, B. C. (1994), "R\&D and Internal Finance: A Panel Study of Small Firms in High-Tech Industries", The Review of Economics and Statistics, 76(1): 38-51.

Huergo, E. and Trenado, M. (2010), "The application for and the awarding of low interest credits to finance R\&D projects", Review of Industrial Organization, 37: 237-259.

Hockerts, K. and Wüstenhagen, R. (2010), "Greening Goliaths versus emerging Davids - Theorizing about the role of incumbents and new entrants in sustainable entrepreneurship", Journal of Business Venturing, 25: 481-492.

Horbach, J., Rammer, C. and Rennings, K. (2012), "Determinants of eco-innovations by type of environmental impact - the role of regulatory push/pull, technology push and market pull", Ecological Economics, 78: 112-122.

Hovardas, T. (2016), "Two paradoxes with one stone: a critical reading of ecological modernization", Ecological Economics, 130: 1-7.

International Labor Organization (ILO). (1993), Resolution Concerning the International Classification on Status in Employment (ICSE), Adopted by the Fifteenth International Conference of Labor Statisticians. https://www.ilo.org/global/statistics-and-databases/standards-and-guidelines/resolutions-adopted-by-international-conferences-of-labour-statisticians/WCMS_087562/lang--en/index. htm. [24th February 2019].

Instituto Nacional de Estadística (INE) (2009), España en Cifras, INE, Madrid.

Instituto Nacional de Estadística (INE) (2010), España en Cifras, INE, Madrid.

Jaffe, A. B., Newell, R. G. and Stavins, R. N. (2005), "A tale of two market failures: Technology and environmental policy", Ecological Economics, 54: 164-174.

Kathuria, V. (2007), "Informal regulation of pollution in a developing country: evidence from India", Ecological Economics, 63(2): 403-417.

Kemp, R. (2000), “Technology and Environmental Policy-Innovation Effects of Past Policies and Suggestions for Improvement”, In OECD (ed.), Innovation and the Environment, Paris: OECD Publishing. 
Koga, T. (2003), "Firm size and R\&D tax incentives", Technovation, 23: 643-648.

Kunapatarawong, R. and Martínez-Ros, E. (2016), “Towards green growth: How does green innovation affect employment?", Research Policy, 45: 1218-1232.

Lach, S. (2002), "Do R\&D Subsidies Stimulate or Displace Private R\&D? Evidence from Israel", Journal of Industrial Economics, L: 369-390.

Lachenmaier, S. and Rottmann, H. (2011), "Effects of innovation on employment: A dynamic panel analysis", International Journal of Industrial Organization, 29: 210-220.

Magrama (2013), Environmental Profile of Spain, Ministry of Agriculture, Food and Environment, Madrid.

Murphy, J. and Gouldson, A. (2000), "Environmental policy and industrial innovation: integrating environment and economy through ecological modernization", Geoforum, 31(1): 33-44.

Nidumolu, R., Prahalad, C.K. and Rangaswami, M.R. (2009), "Why sustainability is now the key driver of innovation", Harvard Business Review, 87: 56-64.

Nielsen, M., Ravensbeck, L. and Nielsen, R. (2014), "Green growth in fisheries”, Marine Policy, 46: 43-52.

OECD (2010), Taxation, innovation and the environment, Paris: OECD Publishing.

OECD (2011a), Science, Technology and Industry Scoreboard 2011, Paris: OECD Publishing.

OECD (2011b), Towards Green Growth: A Summary for Policy Makers, Paris: OECD Publishing.

OECD (2014a), OECD Economic Surveys: Spain 2014, Paris: OECD Publishing.

OECD (2014b), OECD Addressing Social Implications for Growth. Session 2, Inclusive Labor Markets for Green Growth, Green Growth and Sustainable Development Forum, 13-14 November 2014, Paris, Paris: OECD Publishing.

OECD (2014c), OECE science, technology and industry outlook 2014, Technical report, Paris: OECD Publishing.

OECD (2015), Environmental Performance Reviews: Spain 2015, Paris: OECD Publishing.

OECD (2017), Enhancing the contributions of SMEs in a global and digitalized economy, Meeting of the OECD Council at ministerial level, 7-8 June 2017, Paris: OECD Publishing.

Patuelli, R., Nijkamp, P. and Pels, E. (2005), "Environmental tax reform and the double dividend: A meta-analytical performance assessment", Ecological Economics, 55: 564-583.

Ploeg, R. V. D. and Withagen, C. (2013), "Green growth, green paradox and the global economic crisis", Environmental Innovation and Societal Transitions, 6: 116-119.

Porter, M. E. and Van der Linde, C. (1995), “Green and Competitive”, Harvard Business Review, 1995: 120-134.

Poschen, P. and Renner, M. (2015), “Green Jobs”, Finance \& Development, 52: 14-17.

Puig Ventosa, I. (2010), "R\&D and environmental investment tax credits in Spain, Annex E", in Taxation, Innovation and the Environment, Paris: OECD Publishing, 197-208.

Ren, S., Li, X., Yuan, B., Li, D. and Chen, X. (2018), “The effects of three types of environmental regulation on eco-efficiency: A cross-region analysis in China", Journal of Cleaner Production, 173: 245-255. 
Rennings, K. (2000), "Redefining innovation - eco-innovation research and the contribution from ecological economics", Ecological economics, 32: 2 319-332.

Rennings, K., Ziegler, A. and Zwick. T. (2004), "The effect of environmental innovations on employment changes: An econometric analysis", Business Strategy and the Environment, 13: 374-387

Rennings, K and Rammer, C. (2011), "The impact of regulation-driven environmental innovation on innovation success and firm performance", Industry and Innovation, 18(03): 255-283.

Takalo, T., Tanayama, T. and Toivanen, O. (2013a), "Estimating the benefits of targeted R\&D subsidies", Review of Economics and Statistics, 95(1): 255-272.

Takalo, T., Tanayama, T. and Toivanen, O. (2013b), "Market failures and the additionality effects of public support to private R\&D: Theory and empirical implications", International Journal of Industrial Organization, 31(5): 634-642.

Triguero, A., Moreno-Mondéjar, L. and Davia, M. A. (2013), "Drivers of different types of eco-innovation in European SMEs", Ecological Economics, 92: 25-33.

UNEP (2011), Towards a Green Economy: Pathways to Sustainable Development and Poverty Eradication - A Synthesis for Policy Makers, Nairobi Kenya. United Nations Environment.

Veugelers, R. (2012), "Which policy instruments to induce clean innovating?", Research Policy, 41: 1770-1778.

Yang, F. and Yang, M. (2015), “Analysis on China's eco-innovations: regulation context, intertemporal change and regional differences", European Journal of Operational Research, 247(3): 1003-1012.

Zhang, J. X., Cai, N., Yang, C. (2015), "Impact of environmental regulation on green growth index of industry in China", China Population Res Environ, 19(6): 85-90.

Zhao, X. L., Zhao, Y., Zeng, S. X. and Zhang, S. F. (2015), "Corporate behavior and competitiveness: impact of environmental regulation on Chinese firms", Journal of Cleaner Production, 86: 311-322.

Zhu, Q., Geng, Y., Sarkis, J. and Lai, K. (2011), "Evaluating green supply chain management among Chinese manufacturers from the ecological modernization perspective", Transportation Research Part E: Logistics and Transportation Review, 47(6): 808-821. 


\section{Resumen}

Existen dudas sobre si las Administraciones son conscientes de las dificultades de los esquemas de incentivos, es decir, su efectividad, las implicaciones y las condiciones que se requieren para que el instrumento de política pueda utilizarse de la mejor manera posible. Utilizando un conjunto de datos de impuestos corporativos para microempresas y PYMES en 2008, estudiamos la relación entre el empleo y dos tipos de incentivos, crédito fiscal e inversión ambiental (IE) y el crédito fiscal por innovación tecnológica (I+D). Los resultados muestran un impacto positivo del crédito fiscal de ambos instrumentos en el empleo para las microempresas y las PYMES. Sin embargo, el impacto del crédito fiscal de I + D es más fuerte que del crédito fiscal de IE, y más fuerte para las microempresas que para las PYMES. Además, los impactos de ambos créditos fiscales son independientes entre sí. Con este análisis, se proporciona evidencia de los impactos de dos tipos de incentivos fiscales en el nivel de empleo para las micro y pymes que son la columna vertebral de una economía como la española. Un resultado importante es que las Administraciones deben seguir comprometidas con las políticas ecológicas y tecnológicas para garantizar que los esquemas de intervención de políticas sean potentes y efectivas.

Palabras clave: política medioambiental, incentivos fiscales mediomabiental, incentivos fiscales a la I+D, empleo, micoempresas, PYMES.

Clasificación JEL: M10, M21, L25, O31, O38 